\title{
Seroprevalence of Igm antibodies against the agents of torch infections among the patients visiting National Public Health Laboratorv. Teku. Kathmandu.
}

\author{
Lamichhane $S^{a}$. Malla $S^{b}$. Basnvat $S^{a}$. Khanal $S^{b}$. Dumre $S^{b}$. Maharian $L^{b}$ and Shrestha $P^{a}$
}

\begin{abstract}
Introduction TORCH. as an acronvm. stands for Toxoplasma gondii. Rubella virus. Cvtomegalovirus (CMV) and Herpes Simplex Virus (HSV). This acronvm has become one of the most recognized in the field of neonatal/perinatal medicine ${ }^{1}$. TORCH infections also pose a threat to immunosubressed patients including HIV/AIDS patients. cancer patients undergoing chemotherapv. transplant recipients etc.
\end{abstract}

Obiective $\quad$ To determine the distribution of TORCH infections among the suspected patients of different age grouns and gender and to correlate this data with different disease conditions.

Methods $\quad$ The present studv was conducted in the Immunologv section of National Public Health laboratorv (NPHL). Teku from Mav to September 2006. Serum sambles collected from 276 suspected patients were tested for TORCH infections bv IgM Enzvme Linked Immunosorbent Assav (IgM-ELISA).

Results Among 276 patients tested for TORCH infections bv IgM-ELISA. 23.2 percent (64/276) patients showed presence of IgM antibodies against one or more TORCH agents. Higher seroprevalence of TORCH (IgM) was found in females $(26.3 \%)$ than in males $(16.3 \%$ ). Seroprevalence percentages of IgM antibodies were T. gondii $(4.9 \%$ in male and $15.7 \%$ in female). Rubella virus $(9.4 \%$ in male and $3.7 \%$ in female). CMV $(14.7 \%$ in male and $11.0 \%$ in female) and HSV $(9.5 \%$ in male and $11.9 \%$ in female).

Conclusion $\quad$ In the present studv on the seroprevalence of antibodies (IgM) against the agents causing TORCH infections. an overall prevalence of T. gondii (13.7\%). Rubella virus (4.7\%). CMV $(11.7 \%)$ and HSV (11.2\%) was found.

Kev words TORCH infection. Serum. IgM. ELISA

\section{Introduction}

Toxoplasma gondii. a protozoan causing toxoplasmosis is most frequentlv acauired orallv bv eating raw meat or exposure to infected cat feaces ${ }^{2}$. Primarv infection in pregnant women mav result in congenital toxoplasmosis while infection in immunocompromised subiects like AIDS patients mav cause potentially fatal Toxoplasma encephalitis ${ }^{3}$. Rubella or German measles is an infectious disease caused bv the rubella virus which is usuallv transmitted bv droplets from the nose or throat that others breathe in. It can also pass through a pregnant woman's bloodstream to infect her unborn child causing Congenital Rubella svndrome ${ }^{4}$.
Cvtomegalovirus (CMV) is the most freauent cause of congenital infection in humans ${ }^{5}$. About 10 to 20 percent of infected infants mav suffer sensorineural hearing loss. ocular damage or impairment of cognitive and motor function ${ }^{6}$. HSV is ubiauitous virus. infecting the maiority of the world's population earlv in life ${ }^{7}$. HSV tvpe 1 (HSV-1) is usuallv associated with primarv infections of the orofacial area and latent infection of the trigeminal ganglion. while HSV-2 is usuallv associated with genital infections and latent infection in sacral ganglia. Although both primarv and recurrent infections are usuallv self-limited. HSV can cause serious diseases such as neonatal

Corresponding Author: Ms. Suiata Lamichhane. E-mail: suiatalamichhane@hotmail.com. Phone: 977-1-4473083. 9841677335. ${ }^{a}$ Central Department of Microbiologv. Tribhuvan Universitv. Kirtipur. ${ }^{b}$ National Public Health Laboratorv (NPHL). Teku. Kathmandu. 
disseminated herpes. viral encephalitis and blinding keratitis ${ }^{8}$.

TORCH infections are uniaue in their pathogenesis and have potentiallv devastating clinical manifestations 9 . Most of the TORCH infections cause mild maternal morbiditv but have serious fetal conseauences and treatment of maternal infection freauentlv has no impact on fetal outcome. Therefore. recognition of maternal disease and fetal monitoring once disease is recognized are important ${ }^{10}$. These infections. acauired in utero. can be severe enough to cause fetal loss or can result in intrauterine growth restriction. prematuritv. or chronic postnatal infection. The degree of severitv is dependent on the gestational age of the fetus when infected. the virulence of the organism. the damage to the placenta. and the severitv of maternal disease $\mathrm{e}^{11}$.

Congenital toxoplasmosis remains an important cause of blindness. although avoiding exposure to cats and uncooked meat can prevent it. The incidence of rubella infection and subseauent congenital rubella svndrome can be lowered bv vaccination. While cvtomegalovirus remains the most common cause of congenital infection even in the developed countries. the possibilitv of effective treatment with Ganciclovir has emerged from recent studies. In neonatal herpes. selective use of cesarean deliverv and antiviral therapv can decrease incidence and improve outcomes ${ }^{9}$.

All women of childbearing age. especiallv. pregnant women and women with bad obstetric historv (BOH) should be screened for TORCH titers (IgG and IgM). Prenatal and newborn screening should be emploved to identifv and treat congenital infections. Immunosupressed patients including HIV/AIDS patients. cancer patients undergoing chemotherapv. transplant recipients etc. should be routinelv tested for TORCH infection agents and treated timelv in order to avoid serious complications.

\section{Materials and Methods}

During Mav to September 2006. a total of 276 blood samples from patients suspected of TORCH infections were collected and processed according to the standard laboratorv protocols. ELISA techniques for the detection of IgM antibodies to TORCH agents (Toxoplasma. Rubella. Cvtomegalovirus and Herpes simplex virus) were performed. Steps involved in ELISA were common to all TORCH agents and were performed as per the instruction of the manufacturer (Human. Germanv) and result was interpreted as positive or negative. Data were statisticallv analvsed using Chi-square test.

\section{Results}

Among 276 patients visiting for TORCH tests. the highest number of patients (157) belonged to the age groun 21-30 vears out of which $125(65.8 \%)$ were female patients and $32(37.2 \%)$ were male patients. This was followed bv 57 patients in the age group $31-40$ vears out of which $32(16.8 \%)$ were female patients and $25(29.1 \%)$ were male patients.

Of the total 276 blood samples. 16.3 percent $(14 / 86)$ of male patients and 26.3 percent $(50 / 190)$ of female patients were positive to one or more TORCH agents.

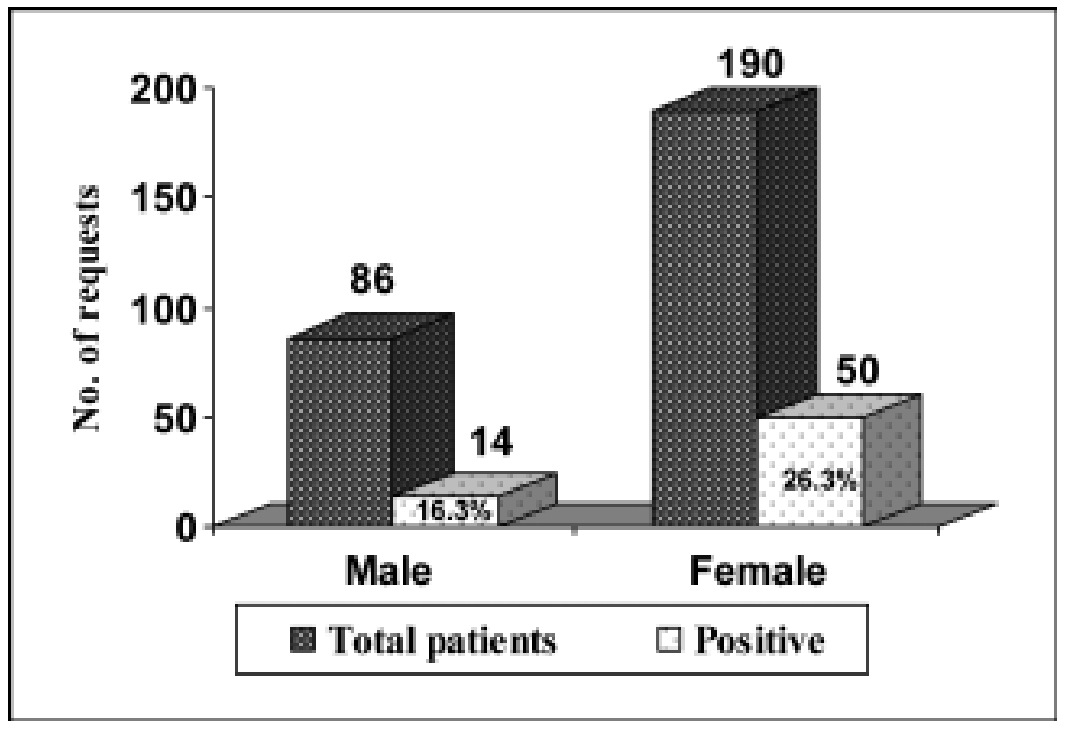

Figure 1: Gender wise distribution of total TORCH tested cases and test result 
Likewise. out of 276 patients. $46(17 \%)$ were found to be infected with single TORCH agent. $18(7 \%)$ with multiple TORCH agents and $212(76 \%)$ were found to be negative.

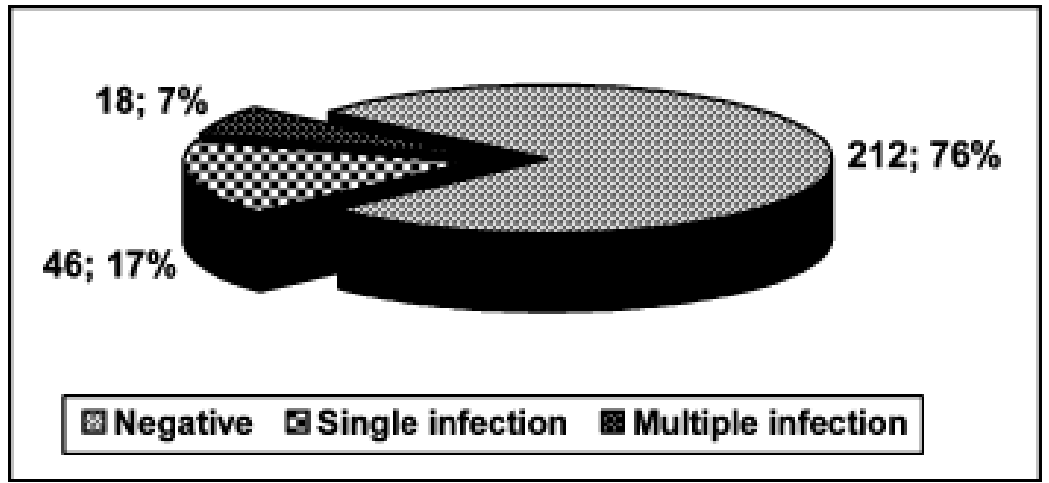

Figure 2: Pattern of torch test results

Distribution of TORCH (IgM) test results in male and female patients was as given in table 1.

Table 1: Gender wise distribution of TORCH (IgM) test results

\begin{tabular}{|c|c|c|c|c|c|c|c|}
\hline $\begin{array}{l}\text { S. Test performed } \\
\text { N. }\end{array}$ & $\begin{array}{l}\text { Total no. of } \\
\text { suspected } \\
\text { cases }\end{array}$ & Gender & $\begin{array}{l}\text { No. of } \\
\text { cases }\end{array}$ & $\begin{array}{l}\text { No. of } \\
\text { positive } \\
\text { cases }\end{array}$ & $\begin{array}{l}\text { Seropositivitv } \\
\text { percentage }\end{array}$ & $\begin{array}{l}\text { Overall } \\
\text { Seropositivitv } \\
\text { percentage }\end{array}$ & D value \\
\hline $\begin{array}{l}\text { 1. ELISA test for } \\
\text { Toxoplasma (IgM) }\end{array}$ & 219 & $\begin{array}{l}\text { Male } \\
\text { Female }\end{array}$ & $\begin{array}{l}41 \\
178\end{array}$ & $\begin{array}{l}2 \\
28\end{array}$ & $\begin{array}{l}4.9 \% \\
15.7 \%\end{array}$ & $13.7 \%$ & $(\mathrm{p}>0.05)$ \\
\hline $\begin{array}{l}\text { 2. ELISA test for } \\
\text { Rubella (IgM) }\end{array}$ & 193 & $\begin{array}{l}\text { Male } \\
\text { Female }\end{array}$ & $\begin{array}{l}32 \\
161\end{array}$ & $\begin{array}{l}3 \\
6\end{array}$ & $\begin{array}{l}9.4 \% \\
3.7 \%\end{array}$ & $4.7 \%$ & $(\mathrm{p}>0.05)$ \\
\hline $\begin{array}{l}\text { 3. ELISA test for } \\
\text { Cvtomegalo } \\
\text { virus (IgM) }\end{array}$ & 197 & $\begin{array}{l}\text { Male } \\
\text { Female }\end{array}$ & $\begin{array}{l}34 \\
163\end{array}$ & $\begin{array}{l}5 \\
18\end{array}$ & $\begin{array}{l}14.7 \% \\
11.0 \%\end{array}$ & $11.7 \%$ & $(\mathfrak{p}>0.05)$ \\
\hline $\begin{array}{l}\text { 4. ELISA test for } \\
\text { Herbes simplex } \\
\text { virus (IgM) }\end{array}$ & 242 & $\begin{array}{l}\text { Male } \\
\text { Female }\end{array}$ & $\begin{array}{l}74 \\
168\end{array}$ & $\begin{array}{l}7 \\
20\end{array}$ & $\begin{array}{l}9.5 \% \\
11.9 \%\end{array}$ & $11.2 \%$ & $(\mathrm{p}>0.05)$ \\
\hline
\end{tabular}

Seropositivity pattern of TORCH agents in patients with different disease conditions was as shown in table 2 .

Table 2: Seropositivitv percentage of TORCH agents in patients with different disease conditions

\begin{tabular}{|c|c|c|c|c|c|}
\hline S. N. & $\begin{array}{l}\text { Patients with different } \\
\text { disease conditions }\end{array}$ & $\begin{array}{l}\text { Seropositivitv } \\
\text { Toxonlasma } \\
\text { (IgM) }\end{array}$ & $\begin{array}{l}\text { Percentage of } \\
\text { Rubella virus } \\
\text { (IgM) }\end{array}$ & $\begin{array}{l}\text { Cvtomegalovirus } \\
\text { (IgM) }\end{array}$ & $\begin{array}{l}\text { Hernes simnlex virus } \\
\text { (IgM) }\end{array}$ \\
\hline$\overline{1 .}$ & $\begin{array}{l}\text { Female with bad obstetric } \\
\text { historv }(\mathrm{BOH})\end{array}$ & $\begin{array}{l}15.43 \\
(25 / 162)\end{array}$ & $\begin{array}{l}4 \\
(6 / 150)\end{array}$ & $\begin{array}{l}9.33 \\
(14 / 150)\end{array}$ & $\begin{array}{l}11.33 \\
(17 / 150)\end{array}$ \\
\hline 2. & $\begin{array}{l}\text { Male (Husbands of female } \\
\text { patients with } \mathrm{BOH} \text { ) }\end{array}$ & $0(0 / 8)$ & $0(0 / 8)$ & $0(0 / 8)$ & $0(0 / 8)$ \\
\hline 3. & $\begin{array}{l}\text { Infants suspected of } \\
\text { congenital infections or those } \\
\text { born to female with } \mathrm{BOH}\end{array}$ & $0(0 / 20)$ & $0(0 / 20)$ & $27.78(5 / 18)$ & $5.55(1 / 18)$ \\
\hline 4. & $\begin{array}{l}\text { Patients suffering from } \\
\text { ocular infection }\end{array}$ & $30(3 / 10)$ & $14.28(1 / 7)$ & $14.28(1 / 7)$ & $14.28(1 / 7)$ \\
\hline 5. & $\begin{array}{l}\text { Patients suffering from } \\
\text { HIV/AIDS }\end{array}$ & $33.33(2 / 6)$ & $16.67(1 / 6)$ & $33.33(2 / 6)$ & $16.67(1 / 6)$ \\
\hline 6. & $\begin{array}{l}\text { Patients suffering from } \\
\text { genital infections }\end{array}$ & - & - & - & $12.76(6 / 47)$ \\
\hline 7. & $\begin{array}{l}\text { Patients with other svmptoms } \\
\text { such as fever. ioint pain. fainting } \\
\text { attacks. paralvsis etc }\end{array}$ & $0(0 / 13)$ & $25(1 / 4)$ & $12.5(1 / 8)$ & $12.5(1 / 8)$ \\
\hline
\end{tabular}




\section{Discussion}

In the present studv on the seroprevalence of antibodies (IgM) against the agents causing TORCH infections. an overall prevalence of T. gondii (13.7\%). Rubella virus (4.7\%). CMV (11.7\%) and HSV (11.2\%) was found as given in table 1. Toxoplasma (IgM) was found to have the highest seroprevalence among the four TORCH agents probablv because in addition to congenital transmission. Toxoplasma is also transmitted orallv bv eating raw meat or exposure to infected cat faeces. And the lowest seroprevalence rate of Rubella (IgM) as compared to other TORCH agents mav be due to Rubella vaccination during the childhood.

The highest number of female patients (125) were found in the age groun 21-30 followed bv 32 in the age groun 31-40 vears. This is probablv because of the fact that females of these age grouns are of childbearing age and are screened for antibodies against TORCH infection agents at their prenatal visits. Though statisticallv insignificant. females showed higher positive rate of 26.3 percent $(50 / 190)$ as compared to 16.3 percent $(14 / 86)$ in males as shown in figure 1. Out of total $276 \mathrm{TORCH}$ infections suspected serum samples. $212(76.8 \%)$ samples showed negative result and $64(23.2 \%)$ samples showed positive result. Out of 64 positive patients. 46 were found to be infected with single and 18 with multiple TORCH agents as evident from figure 2.

Seroprevalence percentages of IgM antibodies were T. gondii $(4.9 \%$ in male and $15.7 \%$ in female patients $)$. Rubella virus $19.4 \%$ in male and $3.7 \%$ in female patients). CMV (14.7\% in male and $11.0 \%$ in female patients) and HSV $(9.5 \%$ in male and $11.9 \%$ in female patients) as given in table 1 . Associations of the presence of $T$. gondii. Rubella virus. CMV and HSV in male and female patients were found to be statisticallv insignificant $(\mathrm{P}>0.05)$.

As evident from table 2. seroprevalence percentages of IgM antibodies were $T$. gondii $(15.4 \%)$. Rubella (4.0\%). CMV (9.3\%) and HSV (11.5\%) in the female patients with bad obstetric historv. Similar Toxoplasma IgM positive rate was found in a studv done bv Rai et $\mathrm{a}^{12}$. In a similar studv carried out in 380 pregnant women with $\mathrm{BOH}$ bv Turbadkar et a ${ }^{13}$ seroprevalence percentages of IgM antibodies were Toxoplasma (10.5\%). Rubella (26.8\%). CMV (8.4\%) and HSV-II $(3.6 \%)$. A higher seroprevalence to TORCH infection was also accounted in a studv conducted bv Thaplival et $\mathrm{al}^{14}$. However. lower seroprevalence of IgM were found in a studv conducted by Kafle et $\mathrm{al}^{15}$ in TORCH suspected Nepalese women of childbearing age.

Likewise. seroprevalence of IgM antibodies were Toxoplasma (0.0\%). Rubella (0.0\%). CMV (27.8\%) and HSV $(5.6 \%)$ in the infants. Among the four TORCH agents under studv. CMV was found to have the highest seroprevalence rate in the infants. This mav be because of the fact that in addition to the placental route. CMV can be transmitted at deliverv via the maternal genital tract. during the post partum period in breast milk and transfused blood products. In a similar studv carried out bv Bos et $\mathrm{a}^{16}$ in Southern Africa. CMV (IgM) positive rate of 19.2 percent was found in female patients with $\mathrm{BOH}$ and that of 24.2 percent was found in the infants.

Similarlv. seroprevalence of IgM antibodv in the patients suffering from ocular infection were found to be 30 percent for Toxoplasma and 14.3 percent for each of Rubella. CMV and HSV. Thus. in our studv. patients suffering from ocular infections were found to have the highest seropositivitv of Toxoplasma which correlates with the studv done bv Jain et a ${ }^{17}$ in India.

Likewise. seroprevalence of IgM antibodies were found to be Toxoplasma (33.3\%). Rubella (16.7\%). CMV (33.3\%) and HSV (16.7\%) in the HIV/AIDS patients. Thus. from our studv. Toxoplasma and CMV were found to be more prevalent opportunistic infectious agents than Rubella and HSV in the HIV/ AIDS patients. This higher Toxoplasma (IgM) positive rates in HIV/AIDS patients is in accordance with the results $\lceil 32 \%(130 / 411)]$ obtained in a similar studv done bv Grant et al ${ }^{18}$. However. the seroprevalence of Toxoplasma ( $\mathrm{IgG} / \mathrm{IgM})$ in HIV infected hosts was found to be higher $(67.8 \%)$ in a similar studv carried out in Bombav bv Meisheri et $\mathrm{al}^{19}$. Similarlv. seroprevalence of HSV IgM antibodies in the patients suffering from genital infections were found to be 12.8 percent (6/47) in our studv.

\section{Conclusion}

The studv was carried out to determine the seroprevalence of TORCH (IgM) among suspected patients visiting NPHL. Teku. Out of total 276 TORCH suspected serum samples. 23.2 percent (64/ 276) samples showed positive result. An overall prevalence of $T$. gondii $(13.7 \%)$. Rubella virus $(4.7 \%)$. CMV (11.7\%) and HSV (11.2\%) was found in the studv.

Seroprevalence percentages of IgM antibodies were T. gondii (15.4\%). Rubella (4.0\%). CMV (9.3\%) and 
HSV $(11.5 \%)$ in the female patients with bad obstetric historv: Toxoolasma $(0.0 \%)$. Rubella $(0.0 \%)$. CMV $(27.8 \%)$ and HSV (5.6\%) in the infants: Toxoplasma (30.0\%). Rubella (14.3\%). CMV (14.3\%) and HSV $(14.3 \%)$ in the patients suffering from ocular infection and Toxoplasma (33.3\%). Rubella (16.7\%). CMV (33.3\%) and HSV (16.7\%) in the HIV/AIDS patients: Toxoplasma $(0.0 \%)$. Rubella (2.0\%). CMV $(12.5 \%)$ and HSV $(12.5 \%)$ in the patients with other svmptoms (fever. ioint pain. fainting attacks etc). Similarlv. seroprevalence of HSV IgM antibodies in the patients suffering from genital infections were found to be 12.8 percent (6/47) in our studv. Among the patients with different disease conditions. the highest seroprevalence of Toxoplasma. CMV and HSV were found to be in HIV/AIDS patients whereas the highest seroprevalence of Rubella was found in the patients with other svmptoms.

\section{Acknowledgement}

This studv was a part of M.Sc. Microbiologv Thesis of Tribhuvan Universitv and was conducted in the Immunologv section of NPHL. Teku. We would like to thank all the staffs of NPHL for helping us throughout this work.

\section{References}

1. Johnson KE. Overview of TORCH infections. 2006: http://vatients.uptodate.com/topic.asp.

2. Bover KM. Toxoplasmosis: Current status of diagnosis. treatment and prevention. Semin Pediatr Infect Dis 2000: 11:165-71.

3. Mohan B. Dubev ML. Malla N and Kumar R. Seroepidemiological studv of toxoplasmosis in different sections of population of Union Territorv of Chandigarh. J Commun Dis 2002: 34(1):15-22.

4. Hirsch L. Infections: Rubella (German measles). 2006: http://www.kidshealth.org/parent/ infections/Rubella.

5. Enders G. Viral infections of the fetus and neonate. other than Rubella. In: Collier L. Balows A and Sussman M (eds) Toplev and Wilson's Microbiologv and Microbial infections. $9^{\text {th }}$ edition. 1998. Arnold. London. Vol-I. 874.

6. Fowler KB. Stagno S and Pass RF. Maternal age and congenital cvtomegalovirus infection: Screening of two diverse newborn populations: 1980-1990. J Infect Dis 1993: 168:552.

7. Ogilvie MM. Hernes viruses. Medical Microbiologv: A Guide to Microbial infections: Pathogenesis. Immunitv. Laboratorv Diagnosis and Control. 15 $5^{\text {th }}$ edition. 1997. Churchill Livingstone. New York. pp 401-11.
8. Whitlev RJ. Herpes simplex viruses. In: Knipe DM and Howlev PM (eds) Fields virologv. $4^{\text {th }}$ edition. 2001. Lippincott. Williams and Wilkins. Philadelphia. Pa. pv 2461-509.

9. Bover SG and Bover KM. Undate on TORCH Infections in the Newborn Infant. NBIN 2004: $4(1)$.

10. Stegmann BJ and Carev JC. TORCH Infections: Toxoplasmosis. Other (svphilis. varicella-zoster. parvovirus B19). Rubella. Cvtomegalovirus (CMV). and Hernes infections. Curr Womens Health Rep 2002: 2(4):253-8.

11. Klein $\mathrm{J}$ and Remington J. Current concents in infections of the fetus and newborn. In: Remington J and Klein J Saunders (eds) Infectious Diseases of the Fetus and Newborn Infant. 2001. Philadelvhia. PA. pp 1-24.

12. Rai SK. Unadhvav MP and Shrestha HG. Toxoplasma infection in selected patients in Kathmandu. Nepal. Nepal Med Coll J 2003: 5(2):89-91.

13. Turbadkar D. Mathur $M$ and Rele $M$. Seroprevalence of torch infection in bad obstetric historv. Indian J Med Microbiol 2003: 21: 108-10.

14. Thaplival N. Shukla PK. Kumar B. Unadhvav S and Jain G. TORCH infection in women with bad obstetric historv-a pilot studv in Kumaon region. Indian J Pathol Microbiol 2005: 48(4):551-3.

15. Kafle P. Jha B. Manandhar SP. Singh A and Adhikari RC. (2004) Seroprevalence of TORCH in Nepalese women of childbearing age and evaluation of biochemical parameters. A dissertation submitted to the central department of Microbiologv. T U. Kathmandu.

16. Bos P. Steele D and Alexander J. Prevalence of antibodies to rubella. herpes simplex 2 and cvtomegalovirus in pregnant women and in neonates at Ga-Rankuwa. Cent Afr J Med 1995: 41(1):14-7

17. Jain SD. Uppal B and Mehta DK. Seroepidemiologv of ocular toxoplasmos is-profile of an urban population. Indian J Pathol Microbiol 1998: 41(4):387-90.

18. Grant IH. Gold JW. Rosenblum M. Niedzwiecki D and Armstrong D. Toxoplasma gondii serologv in HIV-infected patients: the development of central nervous svstem toxoplasmosis in AIDS. AIDS 1990: 4(6):519-21.

19. Meisheri YV. Mehta S and Patel U. A prospective studv of seroprevalence of Toxoplasmosis in general population. and in HIV/AIDS patients in Bombav. India. J Postgrad Med 1997: 43(4):93-7. 